\title{
The Hidden Costs of Livestock Environmental Sustainability: The Case of Podolian Cattle
}

\author{
Ada Braghieri, Corrado Pacelli, Andrea Bragaglio, Emilio Sabia, \\ and Fabio Napolitano
}

\begin{abstract}
Life cycle assessment (LCA) is currently one of the most widely used methods for assessing the environmental impacts and performance of livestock products. According to this procedure, intensification of animal production is generally advocated to mitigate greenhouse gas emissions compared with extensive grazing systems due to the use of selected breeds, with enhanced productivity, and the significant reductions in $\mathrm{CH}_{4}$ emissions consequent to the use of concentrates rather than forages. In addition, the impact of intensive systems on land use is much lower. However, free-ranging Podolian cattle show a number of positive environmental effects, such as increased climate stability, improved soil functionality, water quality and footprint and preservation from fires along with maintaining an economically active social community in otherwise unproductive, marginal areas. Other beneficial effects of extensive Podolian farming system include low competition with human nutrition and high level of animal health and welfare. An economic evaluation of these non-commodity outputs should be indirectly estimated by the avoided costs (e.g. reduced veterinary interventions and therapy treatments) or the lack of profits (e.g. direct payments for the enhancement of environmental performance) that would have incurred in their absence. These economic evaluations should be used in order to allocate them as further outputs to be included in the LCA in order to achieve a more accurate estimation of the impact of the Podolian farming system.
\end{abstract}

\footnotetext{
A. Braghieri $(\bowtie) \cdot$ C. Pacelli • A. Bragaglio • F. Napolitano $(\bowtie)$

Scuola di Scienze Agrarie, Forestali, Alimentari ed Ambientali, Università degli Studi della Basilicata, Via dell'Ateneo Lucano 10, 85100 Potenza, Italy

e-mail: ada.braghieri@unibas.it; fabio.napolitano@unibas.it

E. Sabia

Consiglio per la Ricerca in Agricoltura e l'Analisi dell'Economia Agraria - Unità di ricerca per la Zootecnia Estensiva, Via Appia Bella Scalo, 85054 Muro Lucano, Potenza, Italy
} 


\section{Introduction}

According to The State of Food and Agriculture 2009, the agriculture sector is the world's largest user of natural resources (FAO 2009). Taking into account the entire livestock commodity chain, from land use and feed production, to livestock farming and waste management, to product processing and transportation, the livestock sector plays an important role in climate change, representing $14.5 \%$ of humaninduced greenhouse gas (GHG) emissions. Beef and cattle milk production accounts for the majority of the emissions (41 and $20 \%$ of the sector's emissions, respectively). Feed production and processing and enteric fermentation from ruminants are the two main sources of emissions (45 and $39 \%$ of sector emissions, respectively) while manure storage and processing represent $10 \%$ (FAO 2013). Thus, an increased interest in the greenhouse gas (GHG) intensity of food products has induced a lot of discussion in the media regarding the climate impacts of beef production systems.

\section{Environmental Impact Assessment}

Currently, many different methods are used to assess the environmental impacts and performance of livestock products. Life cycle assessment (LCA) is a welldeveloped internationally standardised method and management tool (ISO 14040 2006; ISO 14044 2006) for quantifying the emissions, resources consumed and environmental and health impacts of products throughout their entire life cycle, from raw material extraction through transport, manufacturing and use all the way to the end of their life (from cradle to grave). According to ISO 14040 (2006), LCA consists of four phases: (1) definition of goal and scope of the analysis, the functional unit, the impact categories and the system boundaries; (2) life cycle inventory (collection of data that identify the system inputs and outputs and discharges to the environment); (3) performance of impact assessment (calculating the contributions made by the material and energy inputs and outputs tabulated in the inventory phase to a specified suite of environmental impact categories, e.g. using the SimaPro 8.1 LCA software package); and (4) analysis and interpretation of results (aiming to identify hot spots and possibilities of decreasing environmental impacts of the system).

It is becoming increasingly common to express the environmental impacts of the production of human food commodities as carbon footprints (CFPs), taking into account all GHGs that are produced during the life cycle of a product. CFPs are expressed as $\mathrm{CO}_{2}$-equivalents $\left(\mathrm{CO}_{2}\right.$-eq. $), \mathrm{CH}_{4}$ having a value of 25 and $\mathrm{N}_{2} \mathrm{O}$ a value of 298 (Forster et al. 2007). Ruminant products have higher CFP production compared with other food commodities (Williams et al. 2007); in fact, due to the nature of their diet (based primarily on forages) and digestive system, ruminants produce hydrogen and $\mathrm{CH}_{4}$ during the fermentative digestion of their feed. $\mathrm{CH}_{4}$ 
constitutes a loss of energy equivalent to 2-12\% of gross energy ingested (Johnson and Johnson 1995).

\subsection{Limitations of the Standard Method of Sustainability Assessment}

According to the LCA procedure, intensification of animal production is generally advocated to mitigate GHGs emissions compared with extensive grazing systems. In fact, intensive systems consider the use of selected breeds, with enhanced productivity, associated with significant reductions in $\mathrm{CH}_{4}$ emissions, related to larger use of concentrates rather than forages (Capper 2012). However, these results focus on emission of greenhouse gases of a single product: beef. On the contrary, for extensive farming systems, the outputs in LCA analysis have to refer not only to material products but also to other non-commodity outputs (OECD 2010) and nonmarketable public goods (Tscharntke et al. 2005), named "ecosystem services" (de Groot et al. 2002; Millennium Ecosystem Assessment 2005; Liu et al. 2010) and related to the multifunctional role of livestock, especially in marginal areas.

\section{The Multifunctional Role of Podolian Farming System}

Rather than resource sufficiency, the concept of sustainability in terms of functional integrity is well suited for extensive livestock farming, where domesticated animals, wildlife, forage, non-forage plants and manure display complex relationships and the capability to coexist as different components of a system. Husbandry of native breeds, such as Podolian cattle (Fig. 4.1), can provide an opportunity for a sustainable use of natural ecosystems and maintain an economically active social community in Southern Italy marginal areas. Podolian cattle, in fact, are a local breed, characterized by a high rusticity and are well adapted to live in a semiarid environment with poor vegetation, as suggested by skin pigmentation, welldeveloped dewlap and sturdy hooves. Their most common rearing system is based on either no-shelter pasture or pasture with nocturnal shelter (Napolitano et al. 2005). Most often, cows and calves are not supplemented, whereas young adults receive concentrates in the finishing period (Braghieri et al. 2011a, 2013).

According to Liu et al. (2010), ecosystem services include all the benefits that people obtain from ecosystems and they are divided (Millennium Ecosystem Assessment 2005) into four categories: provisioning services (e.g. food and water), regulating services (e.g. regulation of climate through the storing of carbon and control of local rainfall and removal of pollutants by filtering the air and water), supporting services (e.g. soil preservation and nutrient cycling) and sociocultural services (e.g. labour provision, recreation and provision of historic, scientific and 


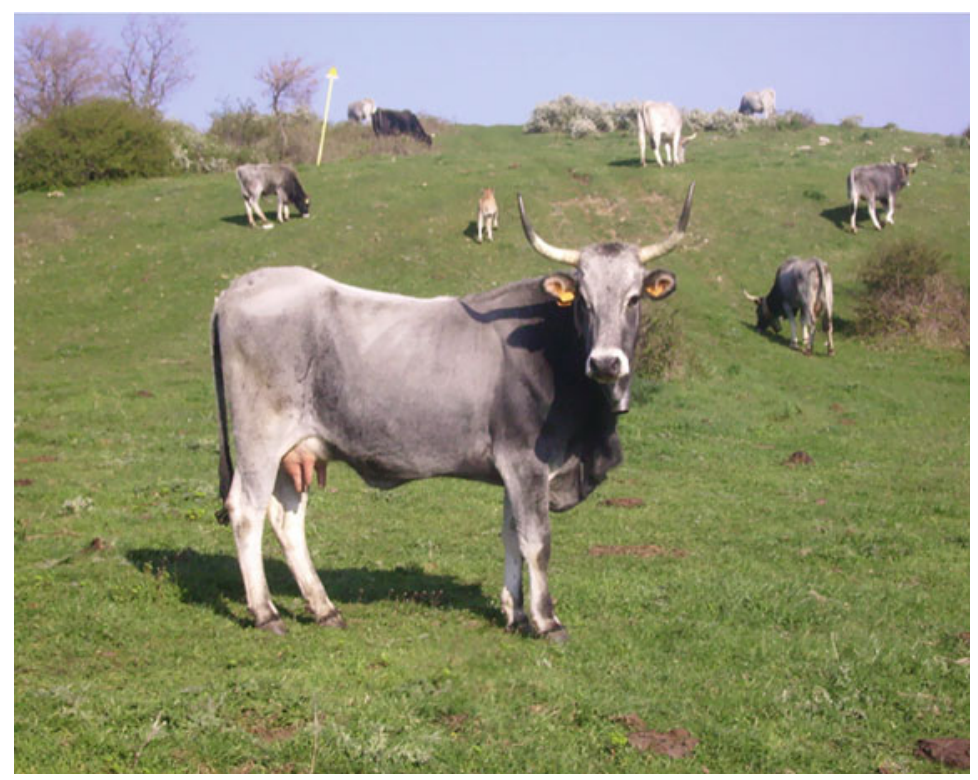

Fig. 4.1 Extensive Podolian farming systems can provide an opportunity for a sustainable use of natural ecosystems and maintain an economically active social community in Southern Italy marginal areas

educational information). Other aspects related to animal production and considered relevant by the public opinion include animal welfare and product quality.

In the next few paragraphs we are going to make a brief analysis, suggesting an economic evaluation of various services provided by Podolian farming system accounting for its multifunctional role in the southern marginal areas of Italy, in order to allocate them as further outputs in LCA analysis.

\subsection{Land Use}

Nearly one-third of terrestrial lands have agricultural crops or planted pastures as a dominant land use (accounting for at least $30 \%$ of total area), thus having a profound ecological effect on the whole landscape (Scherr and McNeely 2008). According to the Eco-indicator 99 methodology of LCA procedure (PRé Consultants), land or occupation of land is considered an important impact category. This parameter showed a heavy impact when considering extensive farming systems, such as Podolian system (Roma et al. 2009). Although LCA software programmes accurately take into account the appropriate datasets, land use impact evaluation should also take into account the quality of the lands used as pasture that in the Podolian system are marginal (upland and of low fertility); therefore, this farming system may represent a tool to maintain an economically active social community 
in these areas. As no realistic alternative to this production system exists, these lands would risk desertification. Conversely, the husbandry of these cattle shows a number of positive environmental effects, such as increased climate stability, improved soil functionality, water quality and footprint and preservation from fires. In addition, positive social and cultural functions, such as labour, touristic activities and production of typical products directly linked to the area, are also promoted.

As for climate stability, permanent grasslands store nearly as much carbon as forests (EIP-AGRI2014). Carbon sequestration potential of permanent pastures was estimated between 0.01 and $0.3 \mathrm{Gt}$ (gross tonnes of volume) $\mathrm{C}_{\text {year }}{ }^{-1}$ (Lal 2004). In addition, a number of management practices, such as maintenance of permanent grassland, adequate grazing pressure, cutting and haymaking, manure application and reduction of tillage, may enhance $\mathrm{C}$ sequestration (Lugato and Berti 2008) and decrease rather than increase $\mathrm{N}_{2} \mathrm{O}$ emissions (Wolf et al. 2010).

Soil functionality, in terms of good structure, sufficient organic matter and resilience to erosion by wind or water, may be improved by the manure of grazing animals, which represents the most important source of nutrients, and organic matter. When deposited directly on pastures and fields, manure does not increase significantly the amount of methane (Bernués et al. 2011).

Intensive rearing systems show a high water footprint (Steinfeld et al. 2006; Hoekstra and Chapagain 2007) in terms of water use (e.g. water embedded in feed production and farming practices and drunk by animals) and water quality (i.e. pollution due to mismanagement of manure, antibiotics and agrochemicals). On the contrary, water-related problems are comparatively irrelevant in low-input systems based on grazing at low stocking densities and on utilisation of local natural resources.

According to de Groot et al. (2002), economic evaluation of these ecosystem services may be indirectly performed by the avoided costs that would have incurred in the absence of these services. Examples are wildfire prevention practices (e.g. cleaning, cutting and partial deforestation) that have relevant costs in terms of human labour and environmental impact or fertilisation and agricultural practices to avoid desertification.

The new Common Agricultural Policy (CAP) introduces a mandatory "greening" component of direct payments for the enhancement of environmental performance (Regulation EU No 1307/2013). Member States should use part of their national ceilings for direct payments in order to grant an annual payment for compulsory practices linked to agriculture, such as crop diversification, the maintenance of permanent grassland and the establishment of ecological focus areas. Regarding permanent grassland, among other aspects, Member States shall ensure that the ratio of areas of permanent grassland to the total agricultural area declared by the farmers will not decrease by more than $5 \%$ compared to a reference ratio to be established by Member States in 2015 . 


\subsection{Lower Competition with Human Nutrition}

There is a growing concern about the use of grains in animal feeding that could be used to produce food eaten by humans (O'Mara 2012). The degree of competition with human nutrition should be another aspect to consider, in terms of sustainable production, as diets in intensive meat systems are mainly based on cereals. Since much of the energy value is lost during conversion from plant to animal matter, it would be much more efficient for humans to consume cereals directly (GerbensLeenes and Nonhebel 2005). In addition, when considering the efficiency of food production, the quantity of human-edible energy and protein used in animal feed should be used rather than gross energy efficiency or protein intake/output ratios (Oltjen and Beckett 1996). Although beef production systems are considerably less efficient than monogastric livestock systems in terms of total energy consumed, recalculating efficiencies of energy and protein production on the basis of humanedible food produced per unit of human-edible feed consumed gave higher efficiencies for ruminants than for monogastric animals (Gill et al. 2009). A low degree of competition with humans was found for Podolian beef production (Napolitano et al. 2005). These animals are able to convert vast renewable resources from grassland, pasture and by-products into food edible for humans. The calculation of human-edible returns should be performed using only gross energy (GE) and crude protein (CP) inputs derived from human-edible foods (Napolitano et al. 2005) and used in the different stages of the Podolian farming system (i.e. cow pregnancy, suckling and weaning of calves and fattening phase).

\subsection{Animal Health and Welfare}

A sustainable animal production system should pursue long-lasting economically competitive activities enabling to minimize any negative effects to the animals, the people, the environment and the community (McGlone and Sutherland 2007). It is obvious that some of these aims are contrasting. For instance, an environmental sustainable farming system should minimize methane emissions by increasing the efficiency of transformation of dietary energy into human-edible products. This approach intends to reduce the amount of fibrous feeds in ruminant feeding while introducing more selected and efficient breeds (FAO 2006). Both strategies may have adverse effects at animal welfare level. The lack of fibre in ruminant nutrition leads to increased levels of disease and abnormal behavioural expressions, such as stereotypies (Fraser 2008). In addition, when native cattle breeds, such as Podolian, are outdoors, they are able to express most of their most relevant natural behaviours, albeit ingesting poor-quality forages while grazing on natural pastures (Braghieri et al. 2011a, b). The substitution of local native breeds with more selected animals may also represent a hazard to animal welfare as these animals are often more susceptible to infectious and production diseases (e.g. Ameni 
et al. 2007) with potentially higher levels of pharmaceuticals involved in the production process.

Napolitano et al. (2010) report that information about animal welfare is an important determinant of consumer willingness to pay (WTP) for various animalbased products. In addition, many producers certify their products with labels (e.g. Animal Welfare Approved, Humane Farm Animal Care, Neuland, Beter Leven) ensuring high standard for farm animal welfare along all the supply chain and receiving a financial reward for that. The indirect market valuation of this noncommodity output could be either performed assessing consumer WTP (de Groot et al. 2002) or evaluating the premium price for animal welfare-friendly products. In addition, the money saved could be quantified as a result of the reduction in veterinary interventions and therapy treatments.

\subsection{Conservation of Biodiversity}

As agriculture has intensified, biodiversity conservation depends primarily on areas with extensive management or on unfarmed features around the farm (e.g. uncultivated strips between crops, walls or hedges and farm tracks) providing food, shelter and breeding sites for birds, mammals and insects and the growing of native flowers and plants. Farmland biodiversity also includes the rich genetic diversity of local breeds of farm animals and varieties of crops well adapted to the soils, vegetation and climate of their region. In addition, natural ecosystems provide habitat to wild plants and animals contributing to the conservation of biological and genetic diversity acting as a "storehouse" of genetic information (de Groot et al. 2002). Livestock intensification, with high breeding selection, and the abandonment of marginal farmland caused a loss of biodiversity. On the contrary, autochthonous breeds can be strategic for adaptation to climate changes in terms of resistance to higher temperature and water scarcity, lower diet quality and disease sensitivity (Hoffmann 2010). Apart from wild ancestors, which for cattle are extinct, and few examples of feral populations (e.g. Hernandez et al. 1999), domestic herds kept in natural environments represent the main source of information about natural behaviour. Podolian cattle, one of the most direct descendants of the ancient wild bovine with a genetic relationship with similar breeds from the Balkans, Anatolia and the Middle East, may be considered a valid example of biodiversity preservation. In fact, they have been subjected to a lower selective pressure (artificial insemination has been rarely used) and a higher natural selection (animals kept in natural environments, where food search, avoidance of predators, maternal care, etc. were essential) as compared with other breeds (Napolitano et al. 2005). In addition, as Podolian cows exhibit a higher degree of adaptability to the local phytocoenosis (e.g. ingestion of ferns), they may also contribute to the preservation of crops biodiversity (Braghieri et al. 2011b). Livestock diet selection is a key issue as it can affect the sensory properties and the nutritional composition of animal-based products (Hadjigeorgiou et al. 2005) with 
positive consequences for human health and for the acquisition of characteristics closely related to the typical rearing environment. This aspect along with some specific genetic characteristics of the Podolian breed can positively influence the nutritional properties of meat (Braghieri et al. 2005; Costa et al. 2013), thus promoting local niche products that can provide higher financial returns for farmers and a wider rural economy.

A major potential driver for biodiversity conservation is represented by the payments to farmers and their communities. According to the new CAP, farmers, probably through a Rural Development Plan (RDP), should be rewarded for the services they deliver to the wider public, even though they have no market value. To this end, a new policy instrument has been introduced in the first pillar (greening) to promote the provision of environmental public goods: the green direct payment, which constitutes a major change in the policy framework. This accounts for $30 \%$ of the national direct payment envelope and rewards farmers for respecting three obligatory agricultural practices, namely, maintenance of permanent grassland, ecological focus areas and crop diversification.

\section{Concluding Remarks}

An economic evaluation of all ecosystem services, non-marketable public goods and non-commodity outputs produced by free-ranging extensive systems, such as the Podolian farming system, should be indirectly estimated either by the avoided costs (e.g. reduced veterinary interventions and therapy treatments) or the lack of profits (e.g. direct payments for the enhancement of environmental performance) that would have incurred in their absence. These economic evaluations should be used in order to allocate them as further outputs to be included in the LCA in order to achieve a more accurate estimation of the impact of the Podolian farming system.

Open Access This chapter is distributed under the terms of the Creative Commons Attribution Noncommercial License, which permits any noncommercial use, distribution, and reproduction in any medium, provided the original author(s) and source are credited.

\section{References}

Ameni G, Aseffa A, Engers H et al (2007) High prevalence and increased severity of pathology of bovine tuberculosis in Holsteins compared to zebu breeds under field cattle husbandry in central Ethiopia. Clin Vaccine Immunol 14:1356-1361

Bernués A, Ruiz R, Olaizola A, Villalba D, Casasús I (2011) Sustainability of pasture-based livestock farming systems in the European Mediterranean context: synergies and trade-offs. Livest Sci 139:44-57 
Braghieri A, Cifuni GF, Girolami A, Riviezzi AM, Marsico I, Napolitano F (2005) Chemical, physical and sensory properties of meat from pure and crossbred Podolian bulls at different ageing times. Meat Sci 69:681-689

Braghieri A, Pacelli C, De Rosa G, Girolami A, De Palo P, Napolitano F (2011a) Podolian beef production on pasture and in confinement. Animal 5(6):927-937

Braghieri A, Pacelli C, Girolami A, Napolitano F (2011b) Time budget, social and ingestive behaviours expressed by native beef cows in Mediterranean conditions. Livest Sci 141:47-52

Braghieri A, Pacelli C, Piazzolla N, Girolami A, Napolitano F (2013) Eating quality of beef from free-range and confined Podolian young bulls. J Anim Sci 91:5885-5893

Capper JL (2012) Is the grass always greener? Comparing the environmental impact of conventional, natural and grass-fed beef production systems. Animals 2:127-143

Costa ASH, Silva MP, Alfaia CPM et al (2013) Genetic background and diet impact beef fatty acid composition and Stearoyl-CoA desaturase mRNA expression. Lipid 48:369-381

de Groot RS, Wilson MA, Boumans RMJ (2002) A typology for the classification, description and valuation of ecosystem functions, goods and services. Ecol Econ 41:393-408

EIP-AGRI Focus Group (2014) Profitability of permanent grassland. How to manage permanent grassland in a way that combines profitability, carbon sequestration and biodiversity? http://ec. europa.eu/eip/agriculture/sites/agrieip/files/fg9_permanent_grassland_profitability_starting paper_2014_en.pdf

EU (2013) Regulation EU No 1307/2013 of the European parliament and of the council of 17 December 2013 establishing rules for direct payments to farmers under support schemes within the framework of the common agricultural policy and repealing Council Regulation (EC) No 637/2008 and Council Regulation (EC) No 73/2009

FAO (2006) Livestock's long shadow. Food and agriculture organization of the United Nations, Rome

FAO (2009) The state of food and agriculture. Food and agriculture organization of the United Nations, Rome

FAO (2013) Tackling climate change through livestock. A global assessment of emissions and mitigation opportunities. Food and Agriculture Organization of the United Nations, Rome

Forster P, Ramaswamy V, Artaxo P et al (2007) Changes in atmospheric constituents and in radiative forcing. In: Qin D, Manning $\mathrm{M}$, Chen $\mathrm{Z}$ et al (eds) Climate change: the physical science basis. Contribution of working group I to the fourth assessment report of the intergovernmental panel on climate change. Cambridge University Press, Cambridge

Fraser D (2008) Understanding animal welfare: the science in its cultural context. Wiley, Oxford

Gerbens-Leenes W, Nonhebel S (2005) Food and land use. The influence of consumption patterns on the use of agricultural resources. Appetite 45:24-31

Gill M, Smith P, Wilkinson JM (2009) Mitigating climate change: the role of domestic livestock. Animal 4(3):323-333

Hadjigeorgiou I, Osoro K, Fragoso de Almeida JP, Molle G (2005) Southern European grazing lands: production, environmental and landscape management aspects. Livest Prod Sci 96:51-59

Hernandez L, Barral H, Halffter G, Colon SS (1999) A note on the behaviour of feral cattle in the Chihuahuan Desert of Mexico. Appl Anim Behav Sci 63:259-267

Hoekstra AY, Chapagain AK (2007) Water footprints of nations: water use by people as a function of their consumption pattern. Water Resour Manag 21:35-48

Hoffmann I (2010) Climate change and the characterization, breeding and conservation of animal genetic resources. Anim Genet 41:32-46

ISO 14040 (2006) Environmental management. Life cycle assessment. Principles and framework

ISO 14044 (2006) Environmental management. Life cycle assessment. Requirements and guidelines

Johnson KA, Johnson DE (1995) Methane emissions from cattle. J Anim Sci 73:2483-2492

Lal R (2004) Soil carbon sequestration impacts on global climate change and food security. Science 304:1623-1627 
Liu S, Costanza R, Farber S, Troy A (2010) Valuing ecosystem services. Theory, practice, and the need for a transdisciplinary synthesis. Ann N Y Acad Sci 1185:54-78

Lugato E, Berti A (2008) Potential carbon sequestration in a cultivated soil under different climate change scenarios: a modelling approach for evaluating promising management practices in north-east Italy. Agr Ecosyst Environ 128:97-103

McGlone JJ, Sutherland M (2007) Towards sustainable livestock production systems. In: Zollitsch W, Winckler C, Waiblinger S, Haslberger A (eds) Sustainable food production and ethics. Wageningen Academic Publishers, The Netherlands, pp 223-228

Millennium Ecosystem Assessment (2005) Ecosystems and human well-being. Island Press, Washington, DC

Napolitano F, Pacelli C, De Rosa G, Braghieri A, Girolami A (2005) Sustainability and welfare of Podolian cattle. Livest Prod Sci 92:323-331

Napolitano F, Girolami A, Braghieri A (2010) Consumer liking and willingness to pay for high welfare animal-based products. Trends Food Sci Technol 21:537-543

O'Mara FP (2012) The role of grasslands in food security and climate change. Ann Bot 110:1263-1270

OECD (2010) Agricultural Policies in OECD Countries. Organisation for Economic Co-OPERATION AND Development. www.oecd.org/tad/agricultural-policies/45539870.pdf

Oltjen JW, Beckett JL (1996) Role of ruminant livestock in sustainable agricultural systems. J Anim Sci 74:1406-1409

Roma R, De Boni A, De Blasi G (2009) Rural development and environmental sustainability-a comparison between typical and conventional meat production systems. In: Abstract of 5th LCA case studies symposium "LCA for decision support in business and government for sustainable consumption and production", Paris, 22-23 Jan 2009

Scherr SJ, McNeely JA (2008) Biodiversity conservation and agricultural sustainability: towards a new paradigm of 'ecoagriculture' landscapes. Philos Trans R Soc Land B Biol Sci 363:477-494

Steinfeld H, Gerber P, Wassenaar T, Castel V, Rosales M, Haan CD (2006) Livestock's long shadow: environmental issues and options. Food and agriculture organization of the United Nations, Rome

Tscharntke T, Klein AM, Kruess A, Steffan-Dewenter I, Thies C (2005) Landscape perspectives on agricultural intensification and biodiversity: ecosystem service management. Ecol Lett 8:857-874

Williams AG, Audsley E, Sandars DL (2007) Environmental burdens of livestock production systems derived from life cycle assessment (LCA). In: Garnsworthy PC, Wiseman J (eds) Recent advances in animal nutrition. Nottingham University Press, Thrumpton, pp 171-200

Wolf B, Zheng XH, Brueggemann N, Chen WW et al (2010) Grazing induced reduction of natural nitrous oxide release from continental steppe. Nature 464:881-884 